\title{
ASSESSMENT OF INTERLABORATORY PRETREATMENT PROTOCOLS BY RADIOCARBON DATING AN ELK BONE FOUND BELOW LAACHER SEE TEPHRA AT MIESENHEIM IV (RHINELAND, GERMANY)
}

\author{
Stuart J Fiedel ${ }^{1}$ John R Southon ${ }^{2} \cdot$ R E Taylor $^{3} \bullet$ Yaroslav V Kuzmin $^{4} \bullet$ Martin Street $^{5} \bullet$ \\ Thomas F G Higham ${ }^{6}$ Johannes van der Plicht ${ }^{7} \cdot$ Marie-Josée Nadeau $^{8} \bullet$ \\ Shweta Nalawade-Chavan ${ }^{6}$
}

\begin{abstract}
Four accelerator mass spectrometry (AMS) facilities undertook an interlaboratory exercise designed to examine the reliability and reproducibility of radiocarbon determinations on bone by dating a sample of elk (Alces alces) from Miesenheim IV. This specimen is derived from a secure geological context directly beneath the Laacher See tephra, which provides a precise terminus ante quem of $\sim 11,060 \mathrm{yr} \mathrm{BP}(\sim 13,050 \mathrm{cal} \mathrm{yr} \mathrm{BP})$. Regrettably, the results of the intercomparison exercise were complicated by evident contamination of the bone sample by exogenous organic material. This contaminant, probably humic acid, resulted in a wide span of ages (10,010 \pm 30 to 11,100 $\pm 45 \mathrm{BP})$. The only method that yielded an accurate determination, consistent with the age of the tephra, was Oxford's single amino acid technique, which targets hydroxyproline. An acid hydrolysis step seems to have been crucial in breaking the bonds between the bone collagen and the contaminant.
\end{abstract}

\section{INTRODUCTION}

Radiocarbon dating of bone samples is challenging. Various laboratories have used and continue to use a variety of pretreatment protocols to extract various types of organic fractions (Longin 1971; Brown et al. 1988; Hedges and van Klinken 1992; Bronk Ramsey et al. 2004; McCullagh et al. 2010; Marom et al. 2012). Greater confidence in the results may be attained by undertaking a suite of analytical checks on the extracted collagen using $\mathrm{C}: \mathrm{N}$ atomic ratios, the collagen yield and carbon content, as well as $\delta^{13} \mathrm{C}$ and $\delta^{15} \mathrm{~N}$ values. Individually, however, these techniques are not sufficiently sensitive to detect low-level contamination in collagen. In several cases, the relative efficacy of these techniques has been tested on an interlaboratory basis (e.g. Ovodov et al. 2011). However, as the true age of the samples is generally unknown, it is often difficult to evaluate the accuracy of the dates; this can only be inferred from paired, presumably associated charcoal-based dates, or by statistical agreement of the bone-based ages (e.g. Potter and Reuther 2012).

Fiedel and Kuzmin (2010) proposed a new, independent interlaboratory test of the reliability and reproducibility of collagen-based dates for Late Glacial fauna. They suggested redating of the Miesenheim IV elk (Alces alces), one of the rare bone samples derived from a precisely dated context (a terminus ante quem date in this case). This largely intact skeleton from the Rhineland region of Germany $\left(50^{\circ} 23^{\prime} \mathrm{N}, 7^{\circ} 25^{\prime} \mathrm{E}\right.$; see Figures $\left.1-3\right)$ was buried, soon after the animal's death, by tephra from the Laacher See volcanic eruption [LST] (Street 1995). This eruption occurred about 200 yr prior to the onset of the Younger Dryas episode in central Europe. In calendar years, this event has been

\footnotetext{
${ }^{1}$ Louis Berger Group, Richmond, Virginia, USA. Corresponding author. Email: sfiedel@louisberger.com.

${ }^{2}$ Keck Carbon Cycle AMS Laboratory, University of California-Irvine, Irvine, California, USA.

${ }^{3}$ Department of Anthropology, University of California-Riverside, Riverside, California, USA; also: Cotsen Institute of Archaeology, University of California-Los Angeles, Los Angeles, California, USA.

${ }^{4}$ Institute of Geology \& Mineralogy, Siberian Branch of the Russian Academy of Sciences, Novosibirsk, Russia.

${ }^{5}$ MONREPOS Archaeological Research Centre and Museum for Human Behavioural Evolution, RGZM, Schloß Monrepos, D-56567 Neuwied, Germany.

${ }^{6}$ Oxford Radiocarbon Accelerator Unit, University of Oxford, Oxford, United Kingdom.

${ }^{7}$ Centre for Isotope Research, University of Groningen, Groningen, the Netherlands; also: Faculty of Archaeology, Leiden University, Leiden, the Netherlands.

${ }^{8}$ Leibniz-Labor, Christian-Albrechts University, Kiel, Germany.
} 


\section{$S$ J Fiedel et al.}

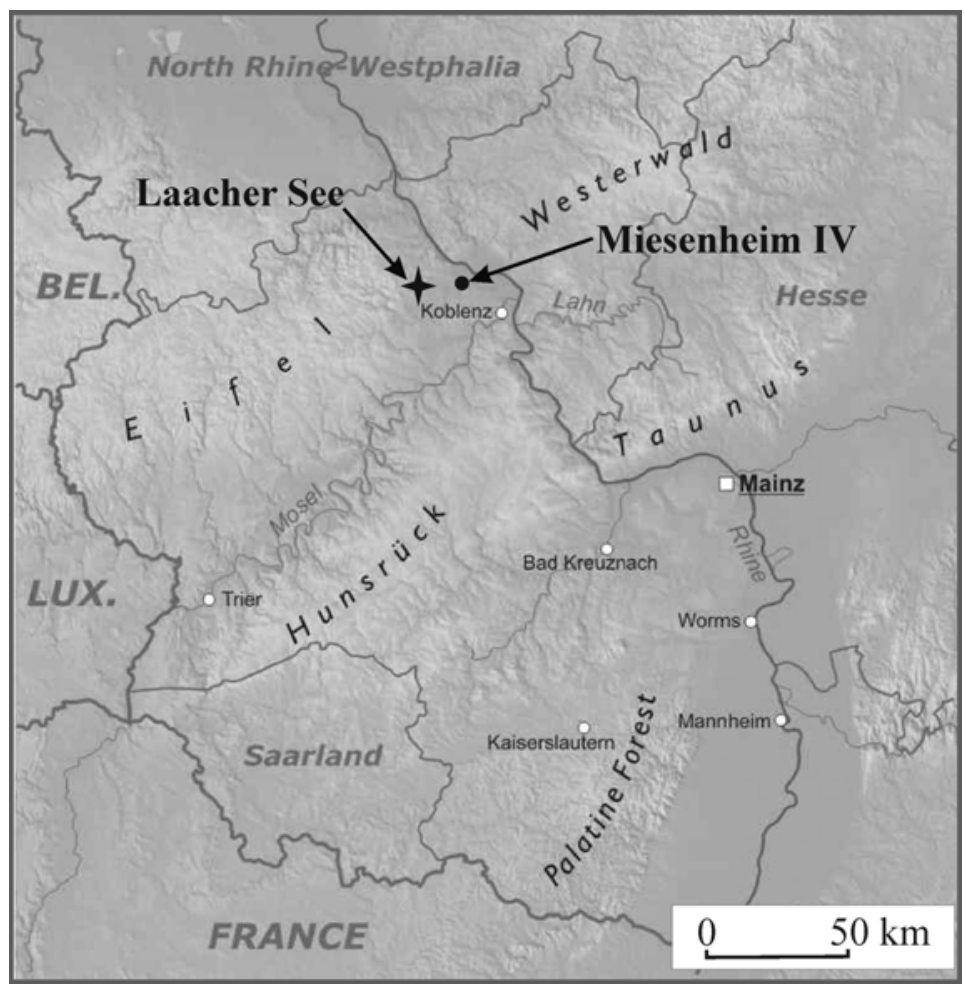

Figure 1 The positions of the Miesenheim IV locality and Laacher See eruption center in Rhineland (Germany).

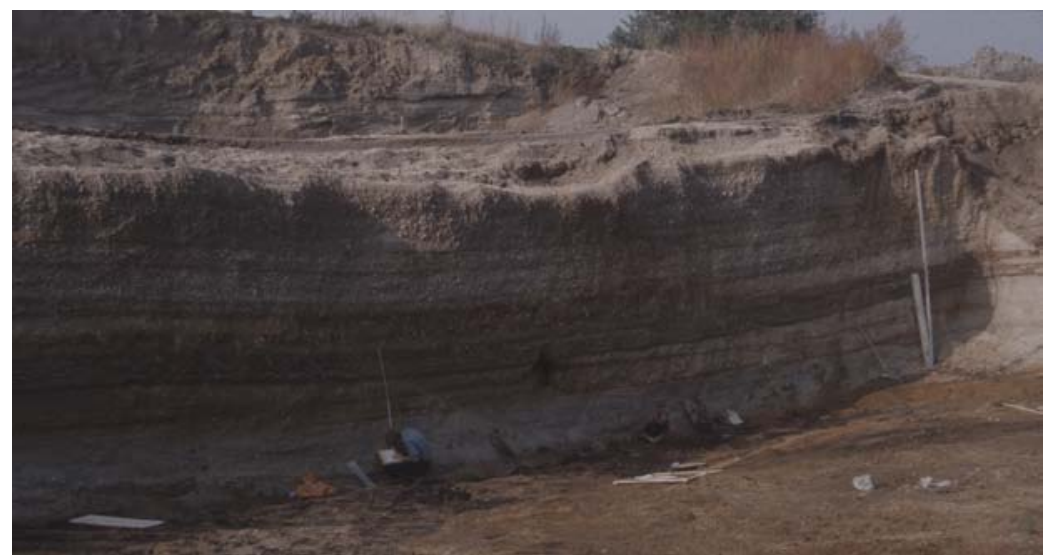

Figure 2 Location of elk remains on surface under thick LST deposits, Miesenheim IV site

dated as late as 12,880 cal BP (Brauer et al. 1999) and as early as 13,050 cal BP (van Raden et al. 2013). To be perfectly clear, it is not our aim here to fix the real age of the eruption. Rather, we assume that the ${ }^{14} \mathrm{C}$ age of the LST has been well established, by dating of tree rings, as $\sim 11,060 \mathrm{BP}$ (Kromer et al. 1998; Friedrich et al. 1999; Baales et al. 2002) (Table 1, see "Kruft" dates). The same age is indicated by a ${ }^{14} \mathrm{C}$ date of $11,040 \pm 60 \mathrm{BP}$ on carbonized vegetation that lay just below the tephra at Miesenheim IV (Bittmann 2007) (Table 2). Although Hajdas et al. (1995) had proposed a 


\section{Assessment of Interlaboratory Pretreatment Protocols}

date of $11,230 \pm 45 \mathrm{BP}$ for the LST, this date seems to have been affected by "old wood" samples. The elk skeleton lay below the LST (Figures $2-3$ ), and its ${ }^{14} \mathrm{C}$ age should therefore be $11,060 \mathrm{BP}$ or slightly older. Previously, 3 samples of the elk from the MONREPOS Museum, Neuwied, Germany, had been submitted by $M$ Street and dated at the Oxford Radiocarbon Accelerator Unit (ORAU), with a mean age of 11,230 \pm 55 BP (Hedges et al. 1993:149-50; Table 3). New samples of the elk bone, which has been stored at Oxford since 1993, were processed and AMS dated by the Groningen, Kiel, University of California-Irvine, and Oxford laboratories. We report here the results of this experiment and discuss their implications.

Table 1 Dates on plant materials from Miesenheim II and other sites in/under the LST (arranged in 2 groups to the south and north of the LS caldera) (after Schweitzer 1958; Frechen 1959; Brunnacker et al. 1982; von den Bogaard and Schmincke 1985; Hedges et al. 1993; Heine 1993; Street et al. 1994; Baales et al. 1998; Kromer et al. 1998; summarized in Baales et al. 2002).

\begin{tabular}{|c|c|c|c|}
\hline Sample & Lab nr & ${ }^{14} \mathrm{C}$ age (yr BP) & Material dated \\
\hline Miesenheim II & Zürich & $10,840 \pm 195$ & Wood (Populus), below LST \\
\hline Miesenheim II & OxA-2612 & $10,880 \pm 110$ & Charcoal sample 1: 42/22 1/4m 3 Niv. 1B \\
\hline Miesenheim II & OxA-2609 & $10,960 \pm 110$ & Wood (Populus sp.) sample 1: 12/11 -11 \\
\hline Miesenheim II & OxA-2610 & $10,960 \pm 110$ & Wood (Populus sp.) sample 2: 20/41 1/4m 3 \\
\hline Miesenheim II & OxA-2611 & $11,030 \pm 110$ & Wood (Populus sp.) sample 3: 32/21 1/4m 3 \\
\hline Miesenheim II & OxA-2613 & $11,040 \pm 110$ & Charcoal sample 2: 11/32 1/4m 4 Niv. 1B \\
\hline Miesenheim II & KN-3519 & $11,040 \pm 220$ & Wood (Populus) 11/24-8 \\
\hline Miesenheim II & OxA-2614 & $11,060 \pm 120$ & Charcoal sample 3: 3/21 1/4m 1 Niv. 1B \\
\hline Miesenheim II & KN-3520 & $11,070 \pm 100$ & Wood (Populus) 13/21-1 \\
\hline Miesenheim II & KN-3518 & $11,080 \pm 220$ & Wood (Populus) 11/24-8 \\
\hline Miesenheim II & KN-3516 & $11,230 \pm 95$ & Wood (Populus) 11/25-1 \\
\hline Miesenheim II & KN-3517 & $11,290 \pm 95$ & Wood (Populus) 11/24-6 \\
\hline Miesenheim II & KN-3534 & $11,360 \pm 110$ & Wood (Populus) 21/24-1 \\
\hline Miesenheim II & KN-3532 & $11,390 \pm 90$ & Wood (Populus) 21/24-1 \\
\hline Miesenheim II & KN-3531 & $11,460 \pm 100$ & Wood (Populus) 18/24-10 \\
\hline Miesenheim II & KN-3533 & $11,460 \pm 90$ & Wood (Populus) 21/24-1 \\
\hline Thelenberg & HD-? & $10,950 \pm 190$ & Charcoal in ULST \\
\hline Nette Valley & W-525 & $10,800 \pm 300$ & Charcoal in MLST \\
\hline Nette Valley & ? & $10,880 \pm 95$ & Charcoal in MLST \\
\hline Kruft & Hd-18648 & $11,037 \pm 27$ & Wood (Populus 1 ring 31-40), in MLST \\
\hline Kruft & Hd-19098 & $11,063 \pm 30$ & Wood (Populus 9 rings $1-20$ ), in MLST \\
\hline Kruft & Hd-18438 & $11,065 \pm 22$ & Wood (Populus 8 outer rings), in MLST \\
\hline Kruft & Hd-19092 & $11,066 \pm 28$ & Wood (Populus 9 rings 21-30), in MLST \\
\hline Kruft & Hd-18622 & $11,073 \pm 33$ & Wood (Populus 9 rings 31-40), in MLST \\
\hline Kruft & Hd-19037 & $11,075 \pm 28$ & Wood (Populus 9 rings 41-50), in MLST \\
\hline Thür & KN-2868 & $11,050 \pm 110$ & Wood (Betula), below LST \\
\hline Thür & KN-2869 & $11,110 \pm 90$ & Wood (Betula), below LST \\
\hline Thür & $\mathrm{KN}-2870$ & $11,250 \pm 95$ & Wood (Betula), below LST \\
\hline Glees & GrN-? & $10,680 \pm 85$ & Charcoal in MLST \\
\hline Brohl Valley & Hv-11774 & $11,075 \pm 185$ & Plant remains In MLST \\
\hline Brohl Valley & $?$ & $11,085 \pm 90$ & Charcoal in MLST \\
\hline Brohl Valley & Hd-17101 & $11,121 \pm 28$ & Tree 5b, 50 rings, in MLST \\
\hline Brohl Valley & Hd-17100 & $11,206 \pm 20$ & Tree 1a, 50 rings, in MLST \\
\hline Brohl Valley & Hd-17145 & $11,223 \pm 22$ & Tree 3a, 50 rings, in MLST \\
\hline Brohl Valley & KN-3800 & $11,240 \pm 100$ & Charcoal (Populus), in MLST \\
\hline Brohl Valley & KN-3801 & $11,260 \pm 95$ & Charcoal (Populus), in MLST \\
\hline Brohl Valley & Hd-17900 & $11,277 \pm 26$ & Tree $1 / 4$, rings $1-38$, in MLST \\
\hline Brohl Valley & KN-3802 & $11,280 \pm 100$ & Charcoal (Populus), in MLST \\
\hline Brohl Valley & KN-3803 & $11,510 \pm 90$ & Charcoal (Populus), in MLST \\
\hline Tönisstein & GrN-? & $11,025 \pm 90$ & Charcoal in MLST \\
\hline Tönisstein & $\mathrm{W}-528$ & $11,150 \pm 200$ & Charcoal in MLST \\
\hline
\end{tabular}




\section{$S$ J Fiedel et al.}

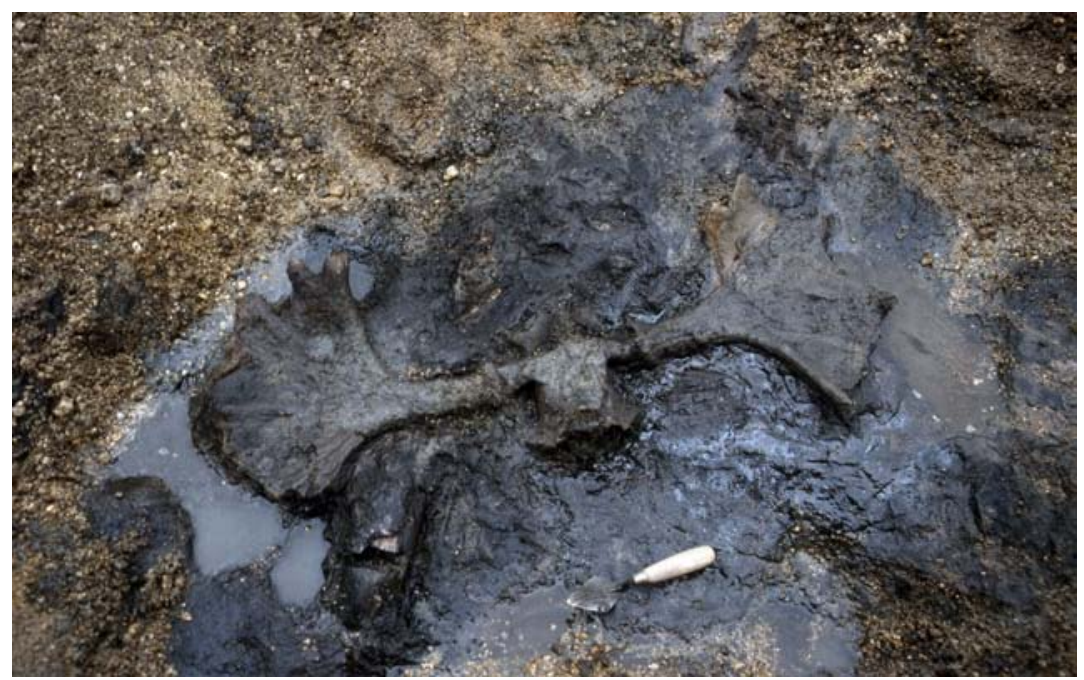

Figure 3 Elk cranium in situ; note water-saturated context

Table 2 Dates on plant materials from Miesenheim IV (mainly after Scharf et al. 2005).

\begin{tabular}{|c|c|c|c|c|}
\hline $\begin{array}{l}\text { Depth } \\
\text { (cm below tephra) }\end{array}$ & $\begin{array}{l}\text { Lab code } \\
\text { and } \mathrm{nr}\end{array}$ & $\begin{array}{l}\delta^{13} \mathrm{C} \\
(\%)\end{array}$ & $\begin{array}{l}\text { Age } \\
\text { (yr BP) }\end{array}$ & $\begin{array}{l}\text { cal yr BC, } \\
2 \sigma \text { range (probability) }\end{array}$ \\
\hline 1 & UtC-4815 & -27.8 & $11,040 \pm 60$ & 11,237-10,916 (0.971) \\
\hline ? & OxA $3587^{a}$ & & $11,170 \pm 100$ & \\
\hline b & & & $11,185 \pm 90$ & \\
\hline 11 & UtC-4816 & -27.2 & $11,490 \pm 60$ & 11,585-11,209 (0.753) \\
\hline 18 & UtC-4817 & -27.7 & $11,810 \pm 60$ & 12,135-11,511 (0.924) \\
\hline 29 & UtC-4818 & -28.1 & $11,910 \pm 80$ & 12,189-11,588 (0.828) \\
\hline 35 & UtC-4819 & -27 & $12,330 \pm 80$ & $\begin{array}{l}13,484-12,567(0.560), \\
12,521-12,145(0.440)\end{array}$ \\
\hline 44 & UtC-4820 & -28.4 & $11,750 \pm 90$ & $12,130-11,479$ (0.953) \\
\hline 53 & UtC-4821 & -28.7 & $12,070 \pm 70$ & 12,393-11,867 (0.702) \\
\hline 64 & UtC-4822 & -27.7 & $12,270 \pm 70$ & $\begin{array}{l}13,460-12,617(0.498), \\
12,468-12,129(0.478)\end{array}$ \\
\hline 73 & UtC-4823 & -27.4 & $12,350 \pm 70$ & $\begin{array}{l}13,477-12,567 \text { (0.573), } \\
12,522-12,157(0.427)\end{array}$ \\
\hline 79 & UtC-4824 & -27.3 & $12,350 \pm 80$ & $\begin{array}{l}13,473-12,560(0.572), \\
12,531-12,155(0.428)\end{array}$ \\
\hline 90 & UtC-4825 & -28.5 & $12,430 \pm 70$ & 13,470-12,190 (1.000) \\
\hline
\end{tabular}

${ }^{a}$ Green moss on elk antler below LST: Hedges et al. (1993).

bBelow LST: Schirmer (1995).

Table 3 Oxford dates on Miesenheim IV elk bones, 1993 (after Hedges et al. 1993).

\begin{tabular}{llll}
\hline Lab nr & Description & $\delta^{13} \mathrm{C}(\%)$ & ${ }^{14} \mathrm{C}$ age $(\mathrm{yr} \mathrm{BP})$ \\
\hline OxA-3584 & $91 / 110-1$, bone, Alces alces & -20.8 & $11,190 \pm 90$ \\
OxA-3585 & 91/111-4, bone, Alces alces & -19.5 & $11,310 \pm 95$ \\
OxA-3586 & 91/111-3, bone, Alces alces & -20.4 & $11,190 \pm 100$ \\
\hline
\end{tabular}




\section{Assessment of Interlaboratory Pretreatment Protocols}

\section{METHODS}

\section{Groningen}

The sample underwent standard chemical cleaning and collagen extraction following Longin (1971). The collagen was combusted into $\mathrm{CO}_{2}$ gas, which was cryogenically trapped using an automatic device (Aerts-Bijma et al. 2001), transformed into graphite, and measured for ${ }^{14} \mathrm{C}$ age (van der Plicht et al. 2000). The ${ }^{14} \mathrm{C}$ activities were measured relative to a standard radioactivity, corrected for isotopic fractionation using the stable isotope ratio ${ }^{13} \mathrm{C} /{ }^{12} \mathrm{C}$ to $\delta^{13} \mathrm{C}=-25 \%$, calculated using the conventional ${ }^{14} \mathrm{C}$ half-life, and reported in yr BP (Mook and van der Plicht 1999).

\section{Oxford}

The dates run at Oxford in 1993 were done using an ion exchange of gelatin technique. The bone was decalcified, treated with alkali, and then with $6 \mathrm{M} \mathrm{HCl}$ for $8-12 \mathrm{hr}$ at $105^{\circ} \mathrm{C}$. The latter treatment hydrolyzed the amino acids, which were then run through ion exchange columns with a Biorad AG50X8 cation exchange resin (Gillespie and Hedges 1983). New dates at the ORAU were undertaken using 2 different preparative methods. The first was the routine ultrafiltration method described in Bronk Ramsey et al. (2004), Higham et al. (2006), and Brock et al. (2007, 2010). This utilizes a final ultrafiltration molecular weight cut-off step based on Brown et al. (1988) using a Vivaspin $^{\mathrm{TM}} 1530 \mathrm{kDa}$ ultrafiltration of the extracted gelatin. The second was the extraction of a single amino acid (hydroxyproline) from hydrolyzed bone collagen using preparative chromatography (McCullagh et al. 2010; Marom et al. 2012). The ORAU pretreatment, graphitization, and AMS methods have been previously described in Brock et al. (2010) and Bronk Ramsey et al. (2004).

\section{Kiel}

The sample was checked and mechanically cleaned under the microscope and then subjected to a Soxhlet-type serial extraction to remove fatty and waxy organic contaminants. In sequence, contaminants were extracted 3 times each with boiling tetrahydrofurane (THF), chloroform, petroleumether, acetone, and methanol, and then rinsed with demineralized water. Pieces of crushed, solid bone material $(0.5-2 \mathrm{~mm})$ were first treated with acetone, rinsed with demineralized water, and subsequently demineralized in $\mathrm{HCl}(\sim 1 \%)$. To remove mobile humic acids, the demineralized bone material was treated with $1 \% \mathrm{NaOH}\left(20^{\circ} \mathrm{C}, 1 \mathrm{hr}\right)$, and again with $1 \% \mathrm{HCl}\left(20^{\circ} \mathrm{C}, 1 \mathrm{hr}\right)$. The preferred dating material, bone collagen, was dissolved overnight as gelatin in demineralized water at $85^{\circ} \mathrm{C}$ and $\mathrm{pH}$ 3. The non-soluble fraction, including a possible contamination, was filtered on a $0.45-\mu \mathrm{m}$ pore silver filter and the gelatin solution was freeze-dried. Standard combustion, graphitization, and AMS measurement techniques at the Kiel laboratory are described in Grootes et al. (2004).

\section{University of California, Irvine (UCIAMS)}

A total of $25{ }^{14} \mathrm{C}$ dates were obtained on the elk bone provided to the UCIAMS laboratory, mostly on ultrafiltered ( $>30 \mathrm{kDa}$ ) gelatin subjected to several different solvent pretreatments (Table 4), and typically with duplicate samples run to assess reproducibility. Procedures used in the preparation of the ultrafiltered gelatin are detailed in Beaumont et al. (2010). Briefly, crushed ( 1 mm) bone samples were decalcified at room temperature for $24-36 \mathrm{hr}$ in $0.5 \mathrm{~N} \mathrm{HCl}$, washed in Milli-Q ${ }^{\mathrm{TM}}$ water, gelatinized overnight in $0.01 \mathrm{~N} \mathrm{HCl}$ at $60{ }^{\circ} \mathrm{C}$, ultrafiltered using $30 \mathrm{kDa}$ Centriprep devices (Brown et al. 1988), and freeze-dried overnight in a vacuum centrifuge. The combustion and graphitization protocols and the operation of the UCIAMS instrument are described in Beverly et al. (2010). Known-age bone standards plus modern and ${ }^{14} \mathrm{C}$-dead bone chemistry blanks were pretreated using the same procedures and measured at the same time as the Miesenheim IV samples. 


\section{$S$ J Fiedel et al.}

An initial set of Miesenheim IV ${ }^{14} \mathrm{C}$ measurements yielded surprisingly young ages and an unusual scatter in the results (groups 1-2 in Table 4). There were no other initial indications that the bone was problematic: $\mathrm{NaOH}$ pretreatment (Group 2) evolved no visible humics; the lyophilized ultrafiltered collagen was white rather than brown; and the stable isotope data and $\mathrm{C}: \mathrm{N}$ ratios were normal (see Results and Discussion below). However, visual examination of both the surface and interior of the bone under magnification clearly revealed an anomalously waxy texture (Figure 2). A series of solvent soaking and sonication pretreatments (Table 4, groups 3-12) were then undertaken on the bone chips, using different solvents to target various types of possible young contaminating organics: water for carpenter's glue; chloroform/methanol for fats and oils; hexanes for alkanes and alkenes; and benzene for aromatics. Nonpolar solvent residues were removed by further sonications in miscible solvents of increasing polarity, followed by a final water treatment. Repeated sonications (e.g. $3 \times 90 \mathrm{~min}$ ) in the Pretreatment column of Table 4 indicate the timing and number of solvent changes. For groups 9-12, the sonicator bath temperature was maintained at $\sim 50{ }^{\circ} \mathrm{C}$ (well below the melting point of collagen) by means of a cooling coil. For groups 11-12, the sonication treatments were performed after decalcification, not before: samples were first decalcified and then sonicated in acetone and freeze-dried prior to the subsequent major sonication treatments, in an attempt to open up the structure of the bone and increase the surface area to allow better solvent access.

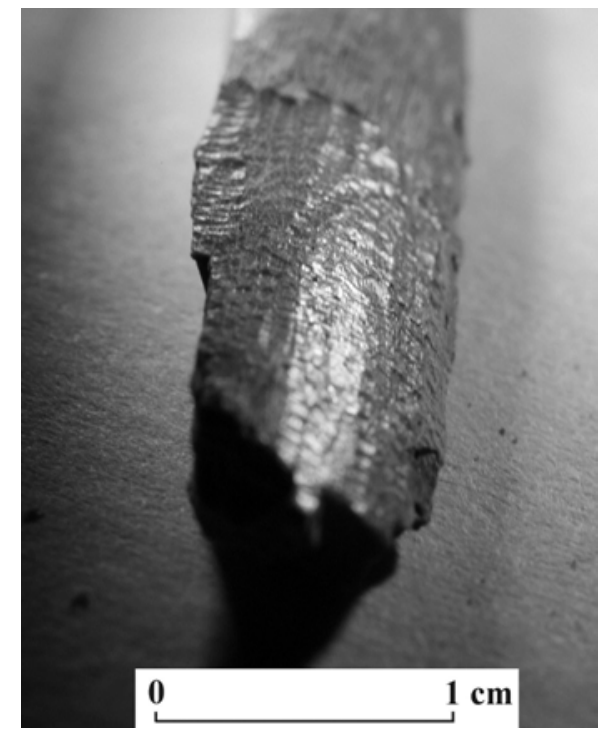

Figure 4 The UCIAMS subsample of the Miesenheim IV elk bone.

\section{RESULTS AND DISCUSSION}

1. Groningen obtained a date on the bone of $10,915 \pm 45 \mathrm{BP}$ (GrA-52434); the $\delta^{13} \mathrm{C}$ is $-20.35 \%$. The nitrogen isotope ratio is measured as $\delta^{15} \mathrm{~N}=2.4 \%$. For the Groningen part of the sample, the C content of the collagen was $42.5 \%$, and the $\mathrm{N}$ content, $13.1 \%$. The atomic C: $\mathrm{N}$ ratio is 3.8 , which is slightly out of the range of 2.9-3.6 that is generally taken as acceptable in paleodiet studies using stable isotopes (Ambrose 1990).

2. Kiel's date is $10,666 \pm 42 \mathrm{BP}$ (KIA 46319); the $\delta^{13} \mathrm{C}$ is $-19.77 \pm 0.29 \%$. C and $\mathrm{N}$ contents were not measured. The collagen yield was $12.3 \%$ and the $C$ yield from collagen was $37 \%$.

3. Oxford's date for ultrafiltered collagen from the rib is $10,625 \pm 50 \mathrm{BP}(\mathrm{OxA}-26093)$; the $\delta^{13} \mathrm{C}$ is $-20.15 \%$ and $\delta^{15} \mathrm{~N}=2.5 \%$. The $\mathrm{C}$ content of the collagen was $43.7 \%$, and the $\mathrm{N}$ content, $15.7 \%$. 


\section{Assessment of Interlaboratory Pretreatment Protocols}

The atomic C:N ratio is 3.2. The date for the hydroxyproline (HYP) amino acid is $11,100 \pm 45 \mathrm{BP}$ (OxA-X-2461-1), the $\delta^{13} \mathrm{C}$ is $-29.2 \%$, and the atomic C:N ratio is 5.0 (note that the theoretical C:N value for hydroxyproline is 5.0). The hydroxyproline date remains unaffected if a correction algorithm is applied for chromatographic background. The hydroxyproline AMS measurement was corrected for background carbon derived from the HPLC as well as the usual combustion, graphitization, and AMS background corrections (see Wood et al. 2010).

Table 4 UCIAMS dates on the Miesenheim IV bone subsample (see Figure 4). Except where noted, all samples were decalcified, gelatinized and ultrafiltered as described in Beaumont et al. (2010). Additional details of the pretreatments and the rationale for the solvent sequences used are given in the Methods section of the text.

\begin{tabular}{|c|c|c|c|c|}
\hline $\begin{array}{l}\text { Group } \\
\mathrm{nr}\end{array}$ & $\begin{array}{l}\text { Fraction dated } \\
\text { (mol wt.) }\end{array}$ & Additional bone pretreatment & $\begin{array}{l}\text { Sample nr } \\
\text { (UCIAMS-) }\end{array}$ & $\begin{array}{l}{ }^{14} \mathrm{C} \text { age } \\
(\mathrm{yr} \mathrm{BP})\end{array}$ \\
\hline 1 & $>30 \mathrm{kDa}$ gelatin & None & $\begin{array}{l}100923 \\
100924\end{array}$ & $\begin{array}{l}10,450 \pm 30 \\
10,015 \pm 30\end{array}$ \\
\hline 2 & $>30 \mathrm{kDa}$ gelatin & $\mathrm{NaOH}$ extraction after decalcification & $\begin{array}{l}100932 \\
100933\end{array}$ & $\begin{array}{l}10,325 \pm 30 \\
10,205 \pm 35\end{array}$ \\
\hline 3 & $>30 \mathrm{kDa}$ gelatin & $\begin{array}{l}\text { Water soak before decalcification: Milli-Q (MQ) water, } \\
36 \mathrm{hr}\end{array}$ & $\begin{array}{l}102870 \\
102871\end{array}$ & $\begin{array}{l}10,424 \pm 50 \\
10,750 \pm 60\end{array}$ \\
\hline 4 & $>30 \mathrm{kDa}$ gelatin & $\begin{array}{l}\text { As for Group3, MQ water soak included } 2 \text { sonications, } \\
24 \mathrm{hr} \text { apart ( } 90 \text { min each) }\end{array}$ & $\begin{array}{l}102872 \\
102873\end{array}$ & $\begin{array}{l}10,720 \pm 60 \\
10,340 \pm 30\end{array}$ \\
\hline 5 & $>30 \mathrm{kDa}$ gelatin & $\begin{array}{l}\text { Sonication before decalcification: } 2: 1 \text { chloroform/metha- } \\
\left.\text { nol, acetone, MQ ( } 60 \text { min each, } 60^{\circ} \mathrm{C}\right)\end{array}$ & 103439 & $10,230 \pm 30$ \\
\hline 6 & Gelatin & As for Group 5, no ultrafitration & $\begin{array}{l}103445 \\
103446\end{array}$ & $\begin{array}{l}10,255 \pm 35 \\
10,160 \pm 25\end{array}$ \\
\hline 7 & $<30 \mathrm{kDa}$ gelatin & As for Group 5, low MW fraction & $\begin{array}{l}103447 \\
103448\end{array}$ & $\begin{array}{l}10,200 \pm 30 \\
10,010 \pm 30\end{array}$ \\
\hline 8 & Decalcified bone & $\begin{array}{l}\text { Sonication before decalcification: hexanes, } 3 \times 60 \mathrm{~min} \text {, } \\
60{ }^{\circ} \mathrm{C} \text { (No gelatinization or ultrafiltration) }\end{array}$ & $\begin{array}{l}103450 \\
103451\end{array}$ & $\begin{array}{l}10,975 \pm 25 \\
10,615 \pm 25\end{array}$ \\
\hline 9 & $>30 \mathrm{kDa}$ gelatin & $\begin{array}{l}\text { Sonication before decalcification: hexanes }(4 \times 30 \mathrm{~min}) \text {, } \\
\text { chloroform/methanol, acetone, methanol ( } 30 \mathrm{~min} \text { each) }\end{array}$ & $\begin{array}{l}104061 \\
104062\end{array}$ & $\begin{array}{l}10,095 \pm 30 \\
10,615 \pm 30\end{array}$ \\
\hline 10 & $>30 \mathrm{kDa}$ gelatin & $\begin{array}{l}\text { Sonication before decalcification: benzene }(9 \times 90 \mathrm{~min}) \text {, } \\
\text { acetone }(3 \times 90 \mathrm{~min}) \text {, MQ water wash }\end{array}$ & $\begin{array}{l}104542 \\
104543 \\
104544\end{array}$ & $\begin{array}{l}10,155 \pm 35 \\
10,315 \pm 35 \\
10,685 \pm 35\end{array}$ \\
\hline 11 & $>30 \mathrm{kDa}$ gelatin & $\begin{array}{l}\text { Sonication after decalcification: i) acetone }(90 \mathrm{~min}) \text {, } \\
\text { freeze-dry; ii) hexanes }(9 \times 90 \mathrm{~min}) \text {, acetone }(3 \times 90 \mathrm{~min}) \text {, } \\
\text { MQ water }(30 \mathrm{~min})\end{array}$ & $\begin{array}{l}105223 \\
105224\end{array}$ & $\begin{array}{l}10,595 \pm 30 \\
10,555 \pm 30\end{array}$ \\
\hline 12 & $>30 \mathrm{kDa}$ gelatin & $\begin{array}{l}\text { Sonication after decalcification: i) acetone }(90 \mathrm{~min}) \text {, } \\
\text { freeze dry; ii) chloroform/methanol }(9 \times 90 \mathrm{~min}) \text {, acetone } \\
(3 \times 90 \mathrm{~min}) \text {, MQ water }(30 \mathrm{~min})\end{array}$ & $\begin{array}{l}105226 \\
105227\end{array}$ & $\begin{array}{l}10,720 \pm 30 \\
10,535 \pm 30\end{array}$ \\
\hline
\end{tabular}

4. The UCIAMS laboratory obtained 25 dates, ranging from $10,015 \pm 30$ to $10,975 \pm 25$ BP (Table 4). Isotopic values for the 2 ultrafiltered collagen aliquots in Group 1 (see Table 4) were $\delta^{15} \mathrm{~N}=2.5 \%$, $\delta^{13} \mathrm{C}=-20.2 \%$; and $\delta^{15} \mathrm{~N}=2.4 \%$, $\delta^{13} \mathrm{C}=-20.3 \%$, and both yielded identical $\mathrm{C}$ and $\mathrm{N}$ contents of $43.8 \%$ and $15.7 \%$, respectively. The isotopic values are normal for herbivores with a 


\section{$S$ J Fiedel et al.}

$\mathrm{C}_{3}$ diet; and the atomic $\mathrm{C}: \mathrm{N}$ ratio of 3.26 is well within the usual range of $\sim 3.15$ to 3.45 for ultrafiltered collagen, which is typically far more tightly constrained than values obtained using more traditional collagen preparation procedures. Nevertheless, all of the UCI ${ }^{14} \mathrm{C}$ results appear to have been significantly affected by varying amounts of contaminating exogenous organics that could not be removed from the bone by a variety of solvent treatments followed by ultrafiltration.

Oxford's hydroxyproline-based age (11,100 $\pm 45 \mathrm{BP}$; OxA-X-2461-6) is the only ${ }^{14} \mathrm{C}$ measurement that falls squarely in the expected range ( 11,060 BP) using $1 \sigma$ criteria. Groningen's date (10,915 \pm $45 \mathrm{BP}$; GrA-52434) is close but too young, even at $2 \sigma$. Only 1 of the 25 UCIAMS dates (10,975 \pm 25 BP; UCIAMS-103450) is close to the expected age, but like the Groningen date, with which it overlaps, it is slightly too young. Ten of the UCIAMS dates are in the range 10,530 to $10,750 \mathrm{BP}$, evidently equivalent to Oxford's ultrafiltered sample date of 10,625 \pm 50 BP (OxA-26093) and the Kiel date of 10,666 \pm 42 BP (KIA 46319).

${ }^{14} \mathrm{C}$ dating of the landscape buried under the LST has been plagued by problems for decades. Not only bones, but also wood and charcoal samples from LST sites have yielded dates somewhat younger than anticipated. Most of these are in the range $10,800-10,950 \mathrm{BP}$, but the youngest (rejected) is 10,680 $\pm 85 \mathrm{BP}$ (Baales et al. 2002). Prior to 1992, Oxford had dated various samples from the Niederbieber I-IV and Miesenheim II sites (Table 5), and it was suspicion that preservatives might have affected some of those dates that led M Street to bring untreated bone samples from the Miesenheim IV excavations to the Oxford lab in early 1992. There is no record of the bones having been conserved using any extraneous substance since that time.

Table 5 Dates on bone from Niederbieber I-IV, Miesenheim II, and Urbar. ${ }^{\text {a }}$

\begin{tabular}{|c|c|c|c|c|c|}
\hline Sample ID & Date BP & Site & Species ID & $\begin{array}{l}\text { Weight } \\
\text { (g) }\end{array}$ & $\begin{array}{l}\text { Collagen } \\
\text { TBNS (mg/g) }\end{array}$ \\
\hline \multicolumn{6}{|l|}{ Conserved } \\
\hline OxA-1132 & $10,700 \pm 130$ & Niederbieber I & Cervus elaphus? bone shaft & 12 & 20.0 \\
\hline OxA-1133 & $9750 \pm 240$ & Niederbieber II & Alces alces? bone shaft & 35 & 7.4 \\
\hline OxA-1134 & $6250 \pm 130$ & Niederbieber II & Equus sp. tooth, upper milk molar & 12 & 2.2 \\
\hline OxA-1135 & $11,130 \pm 130$ & Niederbieber III & Equus sp. astragalus & 32 & 9.8 \\
\hline OxA-1136 & $10,480 \pm 130$ & Niederbieber IV & Cervus elaphus bone shaft & 9 & 16.1 \\
\hline OxA-2066 & $11,110 \pm 110$ & Niederbieber II & Alces alces bone & & 30.0 \\
\hline \multicolumn{6}{|c|}{ Not conserved } \\
\hline OxA-1138 & $10,600 \pm 100$ & Miesenheim II & Cervus elaphus? bone shaft & 2 & 13.6 \\
\hline OxA-2067 & $10,390 \pm 100$ & Niederbieber VII & Cervus elaphus? bone & & 7.6 \\
\hline OxA-2068 & $10,820 \pm 110$ & Miesenheim II & Capreolus capreolus? bone & & 107.0 \\
\hline \multicolumn{6}{|l|}{ Conserved } \\
\hline OxA-1137 & $11,350 \pm 120$ & Urbar & Cervus elaphus, radius shaft & 16 & \\
\hline
\end{tabular}

${ }^{a}$ From Street et al. (1994) and sample records/ORAU correspondence with M Street.

However, although we cannot yet account for the previously encountered inconsistencies in ${ }^{14} \mathrm{C}$ dating the LST, the results of our experiment are best explained as a consequence of either: (1) pervasive postdepositional contamination below the LST by later humic substances that have not been removed by any chemical pretreatments other than hydrolysis; or (2) contamination in the recent past of some of the bone samples submitted for analysis by preservatives or some other exogenous organic(s). We reiterate, though, that there is no record from either Neuwied (the MONREPOS Museum) or Oxford of any conservation chemicals having been applied. Thus, the first explanation, in situ contamination, seems the more probable. This is also supported by the Fourier transform infrared (FTIR) spectroscopy performed at ORAU to test for the presence or absence of any consolidants. FTIR spectra of outer and inner layers of the elk bones were compared with those of a pig rib 
from the wreck of the Tudor warship Mary Rose (AD 1545), an ORAU in-house standard known to be un-conserved (Bronk Ramsey et al. 2004). Infrared spectra were obtained using a Varian Excalibur series FTIR with Digilab Resolutions Pro 4.0 software. The comparison of elk bone spectra (Figure 5) with that of Mary Rose pig bone (Figure 6) in the fingerprint region does not indicate presence of any conservation chemical.

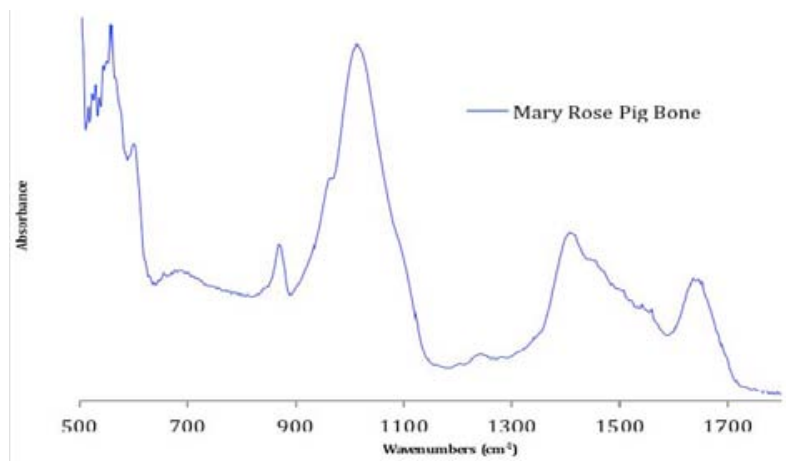

Figure 5 FTIR spectra of pig bone from the Mary Rose

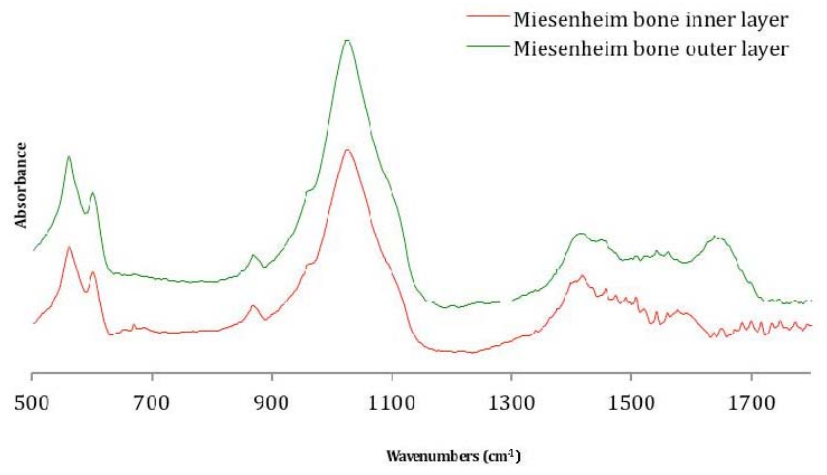

Figure 6 The elk bone FTIR spectra

Although very little water has percolated through the dense tephra, lateral movement of groundwater below the tephra has been observed. At Miesenheim II, pumice removal revealed water running downslope, which immediately formed active erosion channels. Miesenheim IV was waterlogged below the tephra, which accounts for the excellent preservation of bone and vegetation (see Figure 3). This water is certainly not a closed system and perhaps could be the source of younger humic contaminants. The condition of the bone, and its immediate burial environment, was very dark and stained. Surrounding the skeleton was an almost tar-like substance that indicates the likely presence of humic acids. This substance may be the cause of the waxy, shiny appearance of the bone.

\section{CONCLUSION}

Although the anticipated age of the Miesenheim IV elk bone was 11,060 BP, most of the dates obtained were significantly younger. The most parsimonious explanation for the younger results is contamination with more recent in situ carbon that was not completely removed by most of the various chemical pretreatment chemistries applied. This is supported by FTIR analysis that suggests that the contaminant is not likely to be derived from museum or curatorial sources. 


\section{$S$ J Fiedel et al.}

The UCIAMS analyses indicate that the contaminant is not water soluble and it is resistant to various solvents. UCIAMS observed that after prolonged sonication in hexanes and benzene (groups 911 in Table 4), ${ }^{14} \mathrm{C}$ ages for a 19th century cow bone standard were $40-80$ yr too old, indicating that only traces of solvent remained after subsequent processing. Results for this standard with 2:1 chloroform/methanol pretreatments showed that all solvent was removed. Thus, the UCIAMS Miesenheim results are not seriously affected by the presence of solvent treatment residues, and hence the large range in ${ }^{14} \mathrm{C}$ ages obtained from multiple duplicate aliquots subjected to identical pretreatments indicates that the contaminant is non-uniformly distributed within the bone.

Acid hydrolysis to amino acids (performed by the Oxford lab), which will break the strong bonds between humic substances and collagen, seems to be the key step for dating this particular bone. Previous AMS dating done in Oxford using ion exchange methods also produced ages that are approximately consistent with the date of LST deposition. This exercise suggests that the single amino acid approach is reliable even in the presence of undetectable levels of contamination. A compound-specific ${ }^{14} \mathrm{C}$ dating approach isolates a single amino acid from the sample for dating, unlike the other methods applied (including Oxford's own ultrafiltration process), which attempt to remove contaminants from the collagen. In the case of the Miesenheim IV elk, a bone that appears to have been significantly affected by humic contamination, this is the only method of all of those applied in this intercomparison that produced an accurate result (within $1 \sigma$ of the anticipated age).

\section{ACKNOWLEDGMENTS}

The UCIAMS measurements were supported, in part, by the Gabrielle O Vierra Memorial Fund; and Ben Fuller and Simon Fahrni provided valuable laboratory assistance. Travel and participation in the Paris Radiocarbon Conference (July 2012) for YV Kuzmin was provided by the Russian Foundation for Basic Sciences (12-06-00045), Project "Problems of Desertification of Central Asia" of the Russian Academy of Sciences (Program 4.6), and by the Project "GIS Modeling and Spatial Analysis of Environmental Systems and Their Components" of Siberian Branch of the Russian Academy of Sciences (Program IV.31.2).

\section{REFERENCES}

Aerts-Bijma AT, van der Plicht J, Meijer HAJ. 2001. Automatic AMS sample combustion and $\mathrm{CO}_{2}$ collection. Radiocarbon 43(2A):293-8.

Ambrose SH. 1990. Preparation and characterization of bone and tooth collagen for isotopic analysis. Journal of Archaeological Science 17(4):431-51.

Baales M, Bittmann F, Kromer B. 1998. Verkohlte Bäume im Trass der Laacher See-Tephra bei Kruft (Neuwieder Becken). Ein Beitrag zur Datierung des Laacher See-Ereignisses und zur Vegetation der Allerød-Zeit am Mittelrhein. Archäologisches Korrespondenzblatt 28:191-204.

Baales M, Jöris O, Street M, Bittmann F, Weninger B, Wiethold J. 2002. Impact of the Late Glacial eruption of the Laacher See volcano, central Rhineland, Germany. Quaternary Research 58(3):273-88.

Beaumont W, Beverly R, Southon JR, Taylor RE. 2010. Bone preparation at the KCCAMS Laboratory. $\mathrm{Nu}$ clear Instruments and Methods in Physics Research B 268(7-8):906-9.

Beverly RK, Beaumont W, Tauz D, Ormsby KM, von
Reden KF, Santos GM, Southon JR. 2010. The Keck Carbon Cycle AMS Laboratory, University of California, Irvine: status report. Radiocarbon 52(2):301-9.

Bittmann F. 2007. Reconstruction of the Allerød vegetation of the Neuwied Basin, western Germany, and its surroundings at 12,900 cal B.P. Vegetation History and Archaeobotany 16(2-3):139-56.

Brauer A, Endres C, Gunter C, Litt T, Stebich M, Negendank FFW. 1999. High resolution sediment and vegetation responses to Younger Dryas climate change in varved lake sediments from Meerfelder Maar, Germany. Quaternary Science Reviews 18(3):321-9.

Brock F, Bronk Ramsey C, Higham T. 2007. Quality assurance of ultrafiltered bone dating. Radiocarbon 49(2):187-92.

Brock F, Higham T, Ditchfield P, Bronk Ramsey C. 2010. Current pretreatment methods for AMS radiocarbon dating at the Oxford Radiocarbon Accelerator Unit (ORAU). Radiocarbon 52(1):103-12.

Bronk Ramsey C, Higham T, Bowles A, Hedges R. 2004. Improvements to the pretreatment of bone at Oxford. 


\section{Assessment of Interlaboratory Pretreatment Protocols}

Radiocarbon 46(1):155-63.

Brown TA, Nelson DE, Vogel JS, Southon JR. 1988. Improved collagen extraction by modified Longin method. Radiocarbon 30(2):171-7.

Brunnacker K, Fruth H-J, Juvigné E, Urban B. 1982. Spätpaläolithische Funde aus Thür, Kreis MayenKoblenz. Archäologisches Korrespondenzblatt 16: 417-27.

Fiedel SJ, Kuzmin YV. 2010. Is more precise dating of Paleoindian expansion feasible? Radiocarbon 52(2): 337-45.

Frechen J. 1959. Die Tuffe des Laacher Vulkangebietes als quartärgeologische Leitgesteine und Zeitmarken. Fortschritte der Geologie in Rheinland und Westfalen 4:363-70.

Friedrich M, Kromer B, Spurk M, Hofmann J, Kaiser KF. 1999. Paleo-environment and radiocarbon calibration as derived from Lateglacial/early Holocene tree-ring chronologies. Quaternary International 61(1):27-39.

Gillespie R, Hedges REM. 1983. Sample chemistry for the Oxford high energy mass spectrometer. Radiocarbon 25(2):771-4.

Grootes PM, Nadeau MJ, Rieck A. 2004. ${ }^{14} \mathrm{C}$-AMS at the Leibniz-Labor: radiometric dating and isotope research. Nuclear Instruments and Methods in Physics Research B 223-224:55-61.

Hajdas I, Ivy-Ochs SD, Bonani G, Lotter AF, Zolitschka B, Schluchter C. 1995. Radiocarbon age of the Laacher See Tephra: 11,230 \pm 40 BP. Radiocarbon 37(2): 149-54.

Hedges REM, van Klinken GJ. 1992. A review of current approaches in the pretreatment of bone for radiocarbon dating by AMS. Radiocarbon 34(3):279-91.

Hedges REM, Housley RA, Bronk Ramsey C, van Klinken GJ. 1993. Radiocarbon dates from the Oxford AMS System: Archaeometry Datelist 16. Archaeometry 35(1):147-67.

Heine K. 1993. Warmzeitliche Bodenbildung im Bølling/ Allerød im Mittelrheingebiet. Decheniana 146:31524.

Higham TFG, Jacobi RM, Bronk Ramsey C. 2006. AMS radiocarbon dating of ancient bone using ultrafiltration. Radiocarbon 48(2):179-95.

Kromer B, Spurk M, Remmele S, Barbetti M, Toniello V. 1998. Segments of atmospheric ${ }^{14} \mathrm{C}$ change as derived from Late Glacial and Early Holocene floating treering-series. Radiocarbon 40(1):351-8.

Longin R. 1971. New method of collagen extraction for radiocarbon dating. Nature 230(5291):241-2.

Marom A, McCullagh J, Higham T, Sinitsyn A, Hedges R. 2012. Single amino acid radiocarbon dating of Upper Palaeolithic modern humans. Proceedings of the National Academy of Sciences of the USA 109(18): 6878-81.
McCullagh JSO, Marom A, Hedges REM. 2010. Radiocarbon dating of individual amino acids from archaeological bone collagen. Radiocarbon 52(2):620-34.

Mook WG, van der Plicht J.1999. Reporting ${ }^{14} \mathrm{C}$ activities and concentrations. Radiocarbon 41(3):227-39.

Ovodov ND, Crockford SJ, Kuzmin YV, Higham TFG, Hodgins GWL, van der Plicht J. 2011. A 33,000-yearold incipient dog from the Altai Mountains of Siberia: evidence of the earliest domestication disrupted by the Last Glacial Maximum. PLoS ONE 6(7): e22821, doi: 10.1371/journal.pone.0022821.

Potter BA, Reuther J. 2012. High resolution radiocarbon dating at the Gerstle River Site, central Alaska. American Antiquity 77(1):71-98.

Scharf BW, Bittmann F, Boettger T. 2005. Freshwater ostracods (Crustacea) from the Lateglacial site at Miesenheim, Germany, and temperature reconstruction during the Meiendorf Interstadial. Palaeogeography, Palaeoclimatology, Palaeoecology 225(1-4):203-15.

Schirmer U. 1999. Pollenstratigraphische Gliederung des Spätglazials im Rheinland. Eiszeitalter und Gegenwart 49:132--43.

Schweitzer HJ. 1958. Entstehung und Flora des Trasses im nördlichen Laacher Seegebiet. Eiszeitalter and Gegenwart 9(1):28-48.

Street M. 1995. Evidence for late Allerød ecology conserved by Laacher See tephra: Miesenheim 2, Miesenheim 4, Thür, Brohl Valley sites, Glees, Krufter Ofen, Wingertsberg. In: Schirmer W, editor. Quaternary Field Trips in Central Europe. Volume 2. Munich: Pfeil. p 928-34.

Street M, Baales M, Weninger B. 1994. Absolute Chronologie des späten Paläolithikums und Frühmesolithikums im nördlichen Rheinland. Archäologisches Korrespondenzblatt 24(1):1-28.

van der Plicht J, Wijma S, Aerts AT, Pertuisot MH, Meijer HAJ. 2000. The Groningen AMS facility: status report. Nuclear Instruments and Methods in Physics Research B 172(1-4):58-65.

van Raden UJ, Colombaroli D, Gilli A, Schwander J, Bernasconi SM, van Leeuwen J, Leuenberger M, Eicher U. 2013. High-resolution late-glacial chronology for the Gerzensee lake record (Switzerland): $\delta^{18} \mathrm{O}$ correlation between a Gerzensee-stack and NGRIP. Palaeogeography, Palaeoclimatology, Palaeoecology (in press), doi: 10.1016/j.palaeo.2012.05.017.

von den Bogaard P, Schmincke H-U. 1985. Laacher See tephra: a widespread isochronous late Quaternary tephra layer in central and northern Europe. Geological Society of America Bulletin 96(12):1554-71.

Wood RE, Bronk Ramsey C, Higham TFG. 2010. Refining the ultrafiltration bone pretreatment background for radiocarbon dating at ORAU. Radiocarbon 52(23):600-11. 